Revista Eletrônica de Direito Processual - REDP.

Rio de Janeiro. Ano 12. Volume 19. Número 1. Janeiro a Abril de 2018

Periódico Quadrimestral da Pós-Graduação Stricto Sensu em Direito Processual da UERJ

Patrono: José Carlos Barbosa Moreira (in mem.). ISSN 1982-7636. pp. 193-213

www.redp.uerj.br

\title{
MOTIVAÇÃO DAS DECISÕES: NOTAS SOBRE SEU CONTEÚDO, HISTÓRICO \\ E ALGUMAS CONTRADIÇÕES DO CPC/15 ${ }^{1}$
}

\section{STATEMENT OF RATIONALE: NOTES ON ITS CONTENT, HISTORY AND SOME CONTRADICTIONS OF THE CPC/15}

José Roberto Sotero de Mello Porto

Pós-graduado em Direito Privado (UCAM). Mestre Doutorando em Direito Processual (UERJ). Defensor Público do Estado do Rio de Janeiro. joserobertomelloporto@gmail.com

Leonardo Faria Schenk Doutor em Direito Processual (UERJ). Professor Adjunto de Direito Processual Civil (UERJ). Advogado. leonardo.schenk@pcpcadv.com.br

RESUMO: O presente artigo busca analisar o conteúdo do princípio da motivação das decisões judiciais, trazendo breve evolução histórica no ordenamento brasileiro e panorama estrangeiro. Em seguida, é exposto seu patamar de exigência no novo Código de Processo Civil e contradições possivelmente advindas da aplicação da teoria da causa madura em sede de recurso contra sentença nula por ausência de fundamentação (art. 1.013 $\left.\S 3^{\circ}\right)$.

PALAVRAS-CHAVE: motivação das decisões; novo código de processo civil; teoria da causa madura.

ABSTRACT: This article aims to analyze the content of the statement of rationale principle on judicial decisions, bringing a brief historical evolution in the Brazilian juridical order and foreign law panorama. Subsequently, its level of exigency in the new Civil Procedure Code is exposed and contradictions possibly arising from the application

\footnotetext{
${ }^{1}$ Artigo recebido em 01/06/2017 e aprovado em 15/11/2017.
} 
Revista Eletrônica de Direito Processual - REDP.

Rio de Janeiro. Ano 12. Volume 19. Número 1. Janeiro a Abril de 2018

Periódico Quadrimestral da Pós-Graduação Stricto Sensu em Direito Processual da UERJ

Patrono: José Carlos Barbosa Moreira (in mem.). ISSN 1982-7636. pp. 193-213

www.redp.uerj.br

of the "causa madura" theory in the appeal against a null sentence for lack of statement of rationale (article $1.013 \S 3$ ).

KEYWORDS: statement of rationale; new Brazilian civil procedure code; "causa madura" theory.

SUMÁRIO: 1. O dever de motivação das decisões 1.1 Histórico e evolução da positivação 1.2. Conteúdo, fundamentos e funções da motivação 2. O dever de motivação no Código de Processo Civil de 2015: senso e contrassenso 3. Conclusão 4. Referências Bibliográficas.

\section{O dever de motivação das decisões}

O atual Código de Processo Civil trouxe uma imensidão de novidades, que passam por meras reorganizações topográficas ou estruturais de certos temas (a temática da execução, por exemplo), pelo advento de institutos impactantes (veja-se o incidente de resolução de demandas repetitivas), até o aprofundamento de noções preexistentes. Nesse último grupo, podemos inserir o atual tratamento da motivação das decisões judiciais, alvo deste trabalho.

Inicialmente, é válido apontar que a questão está prevista de dois modos. O primeiro é o anúncio da importância da garantia da motivação na proa da novel legislação, no capítulo destinado às normas fundamentais do Processo Civil, especificamente no artigo 11 ("fundamentadas todas as decisões"). O segundo diz respeito a dispositivos específicos que tutelam, em detalhes, a maneira de efetivar tal garantia.

Questão prejudicial à análise da nova vestimenta da motivação dada pelo ordenamento processual civil vigente, contudo, parece-nos ser uma breve exposição da evolução histórica da matéria, bem como o exato conteúdo da garantia.

\subsection{Histórico e evolução da positivação}

Não terá sido à toa que o legislador avançou ao tratar da motivação das decisões judiciais. Na verdade, a preocupação não é, de todo, inédita - e, muito menos, exclusiva de nosso país. 
Revista Eletrônica de Direito Processual - REDP.

Rio de Janeiro. Ano 12. Volume 19. Número 1. Janeiro a Abril de 2018

Periódico Quadrimestral da Pós-Graduação Stricto Sensu em Direito Processual da UERJ

Patrono: José Carlos Barbosa Moreira (in mem.). ISSN 1982-7636. pp. 193-213

www.redp.uerj.br

Michele Taruffo remonta ao século VII ao rememorar o desenvolvimento do tema ${ }^{2}$.

Já Barbosa Moreira ${ }^{3}$ aponta que, no século XVIII, iniciou-se o movimento de inserção da obrigação de motivar as decisões em níveis legais, especialmente na França, dentro da onda atinente à Revolução Francesa, que culminou na Lei de Organização Judiciária de 1790. Em seguida, foi a vez da Prússia e da Península Itálica (em Nápoles) ${ }^{4}$.

A tendência prosseguiu no século seguinte, tendo sido esculpido o dever de fundamentar em leis espanhola, alemã, austríaca, para além de novos diplomas francês e italiano. Também no século XX se verificou ampliação do leque de países preocupados com a matéria, passando a envolver Portugal, Argentina e Bélgica, por exemplo ${ }^{5}$.

O movimento ulterior foi, então, o de levar a motivação para o âmbito constitucional. Tal status permitiria maior estabilidade e a erigiria ao patamar de garantia

\footnotetext{
2 "Por ejemplo, ya los jueces longobardos y francos del Regnum Italicum motivaban sus sentencias en un 'buen latino' en los siglos VII y VIII. La práctica de la motivación se difunde después en los Tribunales de varios Estados: Italia, Francia y España. Se trata de una práctica que todavía no es generalizada, pero son ejemplos significativos de la concepción según la cual la sentencia debe indicar de algún modo las razones del fallo. En cualquier caso, después, como en la Florencia de 1500, se preverá que los jueces deban motivar en forma escrita sus sentencias, las cuáles posteriormente serían depositadas en una oficina pública. (...) En realidad, la verdadera novedad más importante que se produce en este período es una Ley francesa de 1790 nos encontramos al comienzo de la Revolución- que prescribe que todas las sentencias sean motivadas. Esta es una novedad decisiva por varias razones. Por un lado, la ley de 1790 destruye las instituciones, en particular a las instituciones judiciales del Antiguo Régimen, y marca el comienzo de la concepción moderna del Juez y del Poder Judicial, que luego será implementada por las leyes napoleónicas." (TARUFFO, Michele. Apuntes sobre las funciones de la motivación. Revista Iberoamericana de Derecho Procesal. v. 4, jul./dez. 2016. Acesso eletrônico.).

${ }^{3}$ BARBOSA MOREIRA, José Carlos. A motivação das decisões judiciais como garantia inerente ao Estado Democrático de Direito. In: Temas de Direito Processual: segunda série. São Paulo: Saraiva, 1988. 2 ed. pp. 86-88.

4 "Nesse período, a mais relevante legislação que tornou expressa a obrigatoriedade da motivação dos pronunciamentos judiciais decisórios, sob notório influxo da Revolução Francesa sucedida um ano antes, foi a lei de organização judiciária editada na França em 1790 (especificamente o art. 15 do título V). No mesmo momento histórico, passou a ser adotada na Prússia a Allgemeine Gerichtsordnung (1793), também estabelecedora da obrigatoriedade de fundamentação das manifestações judiciais decisórias. No século seguinte, a fundamentação obrigatória das decisões judiciais se afiguraria como caráter comum na absoluta maioria dos ordenamentos jurídico-processuais. Cite-se, à guisa de exemplificação, o Code de Procédure Civile de 1807 e a lei de organização judiciária (1810) franceses, esta cominando inclusive a nulidade dos arestos imotivados; de se mencionar ainda, ad exemplum, o Codice di Procedura Civile na Itália (1865) e a Ley de Enjuiciamiento Civil espanhola (1881). Em idêntica toada, as codificações alemã e austríaca (1877 e 1895, respectivamente) também estipularam a motivação obrigatória das decisões judiciais. Já neste século, cuidaram do tema as codificações italiana (1940), portuguesa (1967), argentina (1970) e francesa (1975)." (MELLO, Rogerio Licastro Torres de. Ponderações sobre a motivação das decisões judiciais. Revista de Processo. v. 111, jul./set. 2003. Acesso eletrônico.).

${ }^{5}$ Um inventário completo dos dados históricos pode ser consultado em: CONTE, Francesco. Sobre a motivação da sentença no processo civil: Estado constitucional democrático de direito, discurso justificativo e legitimação do exercício da jurisdição. Rio de Janeiro: Gramma, 2016, pp. 35-157.
} 
Revista Eletrônica de Direito Processual - REDP.

Rio de Janeiro. Ano 12. Volume 19. Número 1. Janeiro a Abril de 2018

Periódico Quadrimestral da Pós-Graduação Stricto Sensu em Direito Processual da UERJ

Patrono: José Carlos Barbosa Moreira (in mem.). ISSN 1982-7636. pp. 193-213

www.redp.uerj.br

fundamental - aspectos que levaram Barbosa Moreira a advogar, em março de 1978, a conveniência da sua previsão expressa também na Constituição brasileira ${ }^{6}$.

Foi o que sucedeu, com pioneirismo, na França, na Constituição do ano III (de 1975), bem como na Itália, por meio da Constituição de 1948, cujo parágrafo $6^{\circ}$ do artigo 111 , inserto na sessão referente às normas sobre a jurisdição (dentro do título que disciplina a magistratura), é assertivo: todos os provimentos (decisões) jurisdicionais devem ser motivados (tutti i provvedimenti giurisdizionali devono essere motivati).

Verifica-se, a rigor, três níveis de disciplina do dever de motivação: a previsão constitucional, a exclusiva tutela legal (infraconstitucional) e a ausência de tratamento expresso $^{7}$.

Ao lado do trato italiano, são exemplos da mais ampla proteção, com norma específica na carta fundamental, o caso espanhol (artigo 120, 3: las sentencias serán siempre motivadas y se pronunciarán em audiencia pública), o português (artigo 250: as decisões dos tribunais que não sejam de mero expediente são fundamentadas na forma prevista na lei), o peruano (artigo 139, 5: La motivación escrita de las resoluciones judiciales en todas las instancias, excepto los decretos de mero trámite, con mención expresa de la ley aplicable y de los fundamentos de hecho en que se sustentan), o belga (artigo 97: tout jugement est motivé. Il est prononcé en audience publique).

Um degrau abaixo encontra-se, hoje, a normativa francesa, vez que a garantia não permanece na atual Constituição, apenas sendo encontrada em diploma legal (artigo 455 do Code de Procédure Civile: Le jugement doit exposer succinctement les prétentions respectives des parties et leurs moyens. Cet exposé peut revêtir la forme d'un visa des conclusions des parties avec l'indication de leur date. Le jugement doit être motivé), assim como a alemã (o $§ 313$ do Zivilprozessordnung traz os requisitos da sentença, e, no ponto 3 ,

\footnotetext{
${ }^{6}$ BARBOSA MOREIRA, José Carlos. Op. cit., p. 95.

7 "Es el caso del proceso canónico, en el que los abogados dicen -y estamos ya en el 1700- que los jueces deben tener cuidado de no dar razones de sus decisiones. La explicación dada es que si el Juez justifica su decisión, la sentencia pierde su autoridad: la idea esencial es que el verdadero poder, sobre todo si se trata de un poder absoluto, no se justifica. Se requiere la obediencia sin ninguna explicación. Estas diferencias en las aproximaciones hacia la motivación duran un largo tiempo. (...) Ya en 1778, una Cédula Real de Carlos III prohíbe a los Jueces españoles motivar sus decisiones, contrarrestando así la práctica de algunos Tribunales, como la Audiencia de Mallorca, que motivaban sus condenas. La razón invocada para justificar esta prohibición es que elaborar la motivación de la sentencia hace perder el tiempo a los jueces y favorece las "cavilaciones' de las partes." (TARUFFO, Michele. Apuntes sobre las funciones de la motivación. Revista Iberoamericana de Derecho Procesal. v. 4, jul./dez. 2016. Acesso eletrônico.).
} 
Revista Eletrônica de Direito Processual - REDP.

Rio de Janeiro. Ano 12. Volume 19. Número 1. Janeiro a Abril de 2018

Periódico Quadrimestral da Pós-Graduação Stricto Sensu em Direito Processual da UERJ

Patrono: José Carlos Barbosa Moreira (in mem.). ISSN 1982-7636. pp. 193-213

www.redp.uerj.br

obriga a exposição dos motivos de fato e de direito: das Urteil enthält den Tag, an dem die mündliche Verhandlung geschlossen worden ist).

Em terras germânicas, aliás, a jurisprudência enxergou a obrigação de motivar as decisões na Constituição, entendendo que o Estado de Direito é, necessariamente, um Estado que se justifica (rechtsfertingender Staat) - permitindo estender, assim, o dever de motivar também para as decisões interlocutórias.

As legislações italiana e portuguesa reiteram o comando constitucional, respectivamente no artigo $132, \S^{\circ}$ (La sentenza deve contenere: 4 . la concisa esposizione dello svolgimento del processo e dei motivi in fatto e in diritto della decisione) e no artigo 154 (1. As decisões proferidas sobre qualquer pedido controvertido ou sobre alguma dúvida suscitada no processo são sempre fundamentadas. 2. A justificação não pode consistir na simples adesão aos fundamentos alegados no requerimento ou na oposição, salvo quando, tratando-se de despacho interlocutório, a contraparte não tenha apresentado oposição ao pedido e o caso seja de manifesta simplicidade.) dos respectivos diplomas processuais civis.

É interessante notar, a respeito das decisões interlocutórias na Itália, que se discutiu longamente se também elas deveriam ser fundamentadas, ante a exceção literal feita pelo artigo 135 (Il decreto non è motivato, salvo che la motivazione sia prescritta espressamente dalla legge; è datato ed è sottoscritto dal giudice o, quando questo è collegiale, dal presidente). Concluiu-se que a imposição constitucional, mais ampla (de fato, abarca todos os provimentos jurisdicionais), bastaria ${ }^{8}$.

Em países ditos de common law, a necessidade de motivação reveste-se de importância ainda maior, na medida em que, no case law, os precedentes são fonte de direito, em uma dinâmica que valoriza a igualdade e a liberdade, ao diminuir a imprevisibilidade da decisão vindoura ${ }^{9}$.

\footnotetext{
8 TARUFFO, Michele. La motivazione della sentenza civile. Milano: CEDAM, 1975. p. 397. CAPPELLETTI, Mauro; VIGORITTI, Vicenzo. Fundamental guarantees of the litigants in civil proceedings: Italy. In: Mauro Cappelletti; Denis Tallon (orgs.). Fundamental Guarantees of the Parties in Civil Litigation. Milano: Giuffrè, 1973. p. 557.

${ }^{9}$ Sobre o assunto, cf.: "O discurso do precedente tem uma dupla direção. De um lado, a observância de precedentes cria imediatamente um tratamento isonômico entre as pessoas. Ou seja, o precedente promove o sentido mais básico de igualdade, que é o de dar tratamento igual a casos iguais. Mas não é só. O discurso do precedente, de outro lado, mostra-se capaz de promover mediatamente a liberdade." (MOTTA, Otávio. Aspectos da justificação das decisões judiciais em perspectiva comparada. Revista de Processo Comparado. v. 2, jul./dez. 2015, p. 201)
} 
Revista Eletrônica de Direito Processual - REDP.

Rio de Janeiro. Ano 12. Volume 19. Número 1. Janeiro a Abril de 2018

Periódico Quadrimestral da Pós-Graduação Stricto Sensu em Direito Processual da UERJ

Patrono: José Carlos Barbosa Moreira (in mem.). ISSN 1982-7636. pp. 193-213

www.redp.uerj.br

Por essa razão estrutural, a ausência de obrigação genérica ${ }^{10}$ nos países de tradição anglo-saxônica não chega a ser uma angústia ${ }^{11}$, ante a exigência já sedimentada do fair trial.

No Brasil, a evolução principiou em caráter infraconstitucional ${ }^{12}$, notadamente nas Ordenações Filipinas ${ }^{13}$, para a parte poder decidir se apelaria ou não de uma decisão e para que os juízes revisores pudessem verificar o (des)acerto do que fora decidido ${ }^{14}$. A propósito, diversos códigos estaduais reproduziam o comando, não sendo rara a previsão de multa para o juiz que o descumprisse.

Posteriormente, o Código de Processo Civil de 1939 decidiu que o magistrado, ao prolatar sentença, deveria expor seus fundamentos de fato e de direito (artigo 280, inciso II). Seu sucessor, o há pouco revogado Código de 1973 estendeu a obrigação também às decisões interlocutórias pelo artigo 165, o qual, ao lado dos artigos 131 e 458, II (que posicionava a motivação como requisito da sentença), levou Barbosa Moreira a enxergar a "adoção categórica e irrestrita do princípio da obrigatoriedade da motivação"15.

\footnotetext{
10 "Estas consideraciones no se aplican, en cambio, para los ordenamientos que -como en el de los Estados Unidos- no existe la obligación general de motivación y admiten que las sentencias de primera instancia no estén motivadas, en especial con referencia a la decisión sobre los hechos. Esto se aplica en particular cuando el jurado decide sobre los hechos, dado que su 'veredict' nunca es motivado." (TARUFFO, Michele. Apuntes sobre las funciones de la motivación. Revista Iberoamericana de Derecho Procesal. v. 4, jul./dez. 2016, p. 239)

${ }^{11}$ ANDREWS, Neil. Decisões judiciais e o dever de fundamentar. Revista de Processo. v. 192, fev. 2011. p. 126.

${ }^{12}$ Como não poderia deixar de ser, vez que, à época, sequer existia Constituição, no sentido hoje conhecido a primeira Constituição portuguesa data de 1822, e a brasileira, de 1824 .

13 "Historicamente, desde há muito o direito brasileiro registra disposições considerando obrigatória a motivação das decisões judiciais, disposições estas oriundas da própria tradição jurídica luso-brasileira. A propósito, convém registrar como textos legais expoentes dessa tradição legislativa as Ordenações Filipinas (Livro III, Título LXVI, n. 7) e, em momento posterior, o Regulamento 737, de 1850, art. 232. Posteriormente, à época das codificações processuais civis estaduais, prestigiou-se a tradição de positivar a regra da necessidade de fundamentação das decisões judiciais. (...) Desta forma, até a edição do Código de Processo Civil de 1939 (inclusive) nota-se omissão legislativa no tangente à necessidade de fundamentação das decisões interlocutórias. Entretanto, a codificação processual civil de 1973 surgiu de modo a suprir a omissão até então havida." (MELLO, Rogerio Licastro Torres de. Ponderações sobre a motivação das decisões judiciais. Revista de Processo. v. 111, jul./set. 2003. Acesso eletrônico.).

${ }^{14}$ Tal era a literalidade do dispositivo, como apontado por Athos Gusmão Carneiro (Sentença mal fundamentada e sentença não fundamentada. Revista de Processo, v. 81, jan./mar. 1996, nota 3): "E para as partes saberem se lhes convém apelar ou agravar das sentenças definitivas, ou vir com embargos a elas, ou aos juízes da mór alçada entenderem melhor os fundamentos por que os juízes inferiores se movem a condenar ou absolver, mandamos que todos nossos desembargadores ou outros julgadores, ora sejam letrados ora não o sejam, declarem especificamente em suas sentenças definitivas, assim na primeira instância, como no caso de apelação ou agravo, as causas em que se fundarem a condenar ou absolver, a confirmar ou a revogar".

${ }^{15}$ Op. cit., p. 86.
} 
Revista Eletrônica de Direito Processual - REDP.

Rio de Janeiro. Ano 12. Volume 19. Número 1. Janeiro a Abril de 2018

Periódico Quadrimestral da Pós-Graduação Stricto Sensu em Direito Processual da UERJ

Patrono: José Carlos Barbosa Moreira (in mem.). ISSN 1982-7636. pp. 193-213 www.redp.uerj.br

Mais contemporaneamente, a Constituição Federal de 1988 dedicou dispositivo

específico voltado a obrigar os órgãos judiciários a motivar suas decisões (artigo 93, IX), que, como norma autoaplicável e efetiva, obriga amplamente os julgadores. Assim, podese dizer que o Código de Processo Civil de 2015 apenas explicitou o conteúdo da garantia constitucional, que também decorre da cláusula geral do devido processo legal ${ }^{16}$.

\subsection{Conteúdo, fundamentos e funções da motivação}

Visto um sucinto histórico e breve panorama global a respeito do tema, cumpre investigar o que se entende por dever de motivação e seus escopos.

Basicamente, pode-se perceber que os ordenamentos em geral consideram motivada uma decisão que exponha os seus fundamentos, tanto de fato como de direito.

Michele Taruffo faz questão de desmitificar a concepção da motivação como uma descrição do procedimento que leva o juiz a chegar à decisão, já que se revelaria impossível a exposição plena do raciocínio. Para o doutrinador italiano, a motivação deve ser entendida como um discurso argumentativo no qual o juiz fornece boas razões para sustentar sua posição coercitiva.

O conteúdo da motivação, portanto, deve ser completo, referindo-se a todos os aspectos relevantes da decisão ${ }^{17}$. Desse modo, divide-se em justificação interna (ligação

\footnotetext{
${ }^{16}$ DINAMARCO, Cândido Rangel; LOPES, Bruno Vasconselos Carrilho. Teoria geral do novo processo civil. 2. ed. São Paulo: Malheiros, 2017, p. 72.

17 "En otras palabras, la motivación debe ser completa, y eso significa que esta debe referirse a todos los aspectos relevantes de la decisión. En particular, esta debe contener una adecuada justificación de la decisión relativa a la verdad o falsedad de las descripciones entorno a los hechos de la causa. Justificar una decisión relativa a la veracidad de un enunciado fáctico significa indicar cuales son los elementos de cognición proporcionados por los medios probatorios que confirman la correspondiente veracidad de los enunciados. Ello implica que el Juez debe tomar en consideración todas las pruebas que son aportada al proceso, no solo aquellas que confirman su decisión, sino también -y quizás sobre todo- aquellas contrarias a dicha decisión. Debe expresar una valoración relativa a la confiabilidad de cada prueba, en vez de una valoración relativa sobre el conjunto de las pruebas disponibles. Estas valoraciones deben, además, fundarse sobre inferencias lógicas que permitan establecer si resultan o no racionalmente fundadas. Así, por ejemplo, el numeral 1 del artículo 192 del Código de Procedimientos Penales italiano señala que la motivación debe indicar los criterios de inferencia que justifican la decisión adoptada con referencia a las pruebas. En esencia, una motivación completa implica la realización de un análisis lógico relativo a toda la información positiva y negativa, sobre la cual se fundamenta el examen final relativo a los hechos de la causa. Vale la pena insistir sobre el requisito de una motivación completa ya que muchas veces se dice, dejando de entender el necesario contenido de la justificación, que el Juez podría limitarse a indicar las pruebas favorables a la versión de los hechos que ha acogido en su pronunciamiento, sin siquiera hacer mención a la información que contradice dicha versión. Se trata de una falacia muy difundida y conocida como 'Confimation bias' que el Juez 'racional' debería evitar. Correctamente, el artículo 546, literal e, del Código de Procedimientos Penales establece que los jueces deben indicar en la motivación las razones por las cuales desestiman las pruebas
} 
Revista Eletrônica de Direito Processual - REDP.

Rio de Janeiro. Ano 12. Volume 19. Número 1. Janeiro a Abril de 2018

Periódico Quadrimestral da Pós-Graduação Stricto Sensu em Direito Processual da UERJ

Patrono: José Carlos Barbosa Moreira (in mem.). ISSN 1982-7636. pp. 193-213

www.redp.uerj.br

lógica entre premissa legal e premissa fática, partindo da subsunção do fato à norma) e

justificação externa (motivação fática, a exemplo das razões de escolher uma prova e não outra, e motivação jurídica, como no caso de eleição de uma tese, entre as várias eventualmente apresentadas).

Com efeito, espera-se que o Estado de Direito ${ }^{18}$ se justifique, material (verificação da existência de fundamentos para a decisão) e formalmente (exposição desses fundamentos).

A prolação da decisão, por parte do Poder Judiciário, deve sempre portar uma carga argumentativa capaz de legitimar-se. Tal percepção decorre da natureza contramajoritária e não necessariamente democrática desse poder estatal, que, sabidamente, não emerge da escolha do povo, fazendo surgir a carência de um freio democratizador ${ }^{19}$.

Nessa linha, o Judiciário, ao tutelar a ordem jurídica, pressupõe que consiga atuar efetiva e eficazmente, devendo a motivação das suas decisões ser tanto mais elaborada, tanto mais perfeita e tanto mais satisfatória e legitimadora quanto maior for a relevância do órgão para a comunidade jurídica interessada na prolação ${ }^{20}$. Evidente, então, que a possibilidade de se explicar não pode ser encarada como um peso para o magistrado, mas sim como um privilégio.

Isso porque, como esclarece Francesco Conte, a motivação da decisão é fator de racionalização da função jurisdicional ao permitir, de um lado, a constatação da razoabilidade das decisões judiciais e ao evitar, de outro, a arbitrariedade no exercício da jurisdição. $^{21}$

Interessante, aqui, abrir um parêntesis. O conteúdo da motivação, além de um aspecto positivo (isto é, o que uma decisão fundamentada deve conter, como visto supra),

contrarias a su decisión." (TARUFFO, Michele. Apuntes sobre las funciones de la motivación. Revista Iberoamericana de Derecho Procesal. v. 4, jul./dez. 2016. Acesso eletrônico.).

${ }^{18}$ LIEBMAN, Enrico Tulio. Do arbítrio à razão. Reflexões sobre a motivação das sentenças. Revista de Processo. v. 29.

19 "Das três faces do poder estatal, o Judiciário é o único que não se submete à escolha popular. Dada a sua característica de não poder prescindir de técnicos conhecedores do ordenamento jurídico e de modo a preservar a sua independência para julgar com imparcialidade, desapegado dos clamores populares e, em certos momentos, contramajoritariamente, o Judiciário tem seus quadros selecionados em concursos públicos que, ao menos em tese, são capazes de filtrar os vocacionados e capacitados para a função jurisdicional." (HELLMAN, Renê Francisco. Sobre como será difícil julgar com o Novo Código de Processo Civil: do prêtà-porter à alta costura decisória. Revista de Processo. v. 239, jan./2015. Acesso eletrônico.).

${ }^{20}$ BARBOSA MOREIRA, Op. cit., p. 89.

${ }^{21}$ CONTE, Francesco. Sobre a motivação da sentença no processo civil: Estado constitucional democrático de direito, discurso justificativo e legitimação do exercício da jurisdição. Rio de Janeiro: Gramma, 2016, p. 516. 
Revista Eletrônica de Direito Processual - REDP.

Rio de Janeiro. Ano 12. Volume 19. Número 1. Janeiro a Abril de 2018

Periódico Quadrimestral da Pós-Graduação Stricto Sensu em Direito Processual da UERJ

Patrono: José Carlos Barbosa Moreira (in mem.). ISSN 1982-7636. pp. 193-213

www.redp.uerj.br

pode estar dotado de um aspecto negativo, assim entendida alguma restrição que o ordenamento coloca ao julgador, que não poderá lançar mão de algo em sua fundamentação.

Caso de relevo, nesse campo de restrições à fundamentação, é o da citação doutrinária no direito comparado. Edilton Meirelles assevera que, enquanto fonte material do direito ${ }^{22}$, nada impede que haja menção a posicionamento de algum autor no bojo da fundamentação decisória. Antes, recomenda-se, em homenagem ao diálogo, o que comumente sucede em nosso país.

Em outros lados, porém, o tratamento envereda por caminhos diversos. Na Itália, o artigo 118 das Disposizioni per l'attuazione del codice di procedura civile e disposizioni transitorie (In ogni caso deve essere omessa ogni citazione di autori giuridici) é peremptório ao refutar a citação, por mais que (i) seja possível se basear no referido posicionamento; e (ii) a jurisprudência tenha assentado a ausência de sanção para o descumprimento da norma.

A ratio do dispositivo é uma inversão do quadro surgido no século XVIII, em que a opinião de juristas gozava quase que de caráter vinculante, situação que se tornaria insustentável com o advento de numerosos trabalhos acadêmicos, variadíssimos ${ }^{23}$.

Mais teratológica ainda foi a praxe britânica de repudiar citações apenas de autores ingleses, decorrente de entendimento do juiz Gibbs, em 1816. A lógica da proibição já

\footnotetext{
22 "Neste sentido é que a doutrina não constitui uma fonte formal do direito, mas, sim, uma fonte material, pois fruto das ideias dominantes numa sociedade. A doutrina não passa, em realidade, da expressão material da cultura de um povo. Ela é fruto do pensamento humano, na interpretação das normas, usos, costumes e valores dominantes numa sociedade." (MEIRELLES, Edilton. A citação da doutrina nas decisões judiciais no direito comparado. Revista de Processo. v. 206, abr./2012,. Acesso eletrônico.).

23 "Era comum, até o século XVI, os litigantes e juízes solicitarem a um jurista um parecer formal ou consilium sapientis. E essas opiniões, em alguns casos, tinham verdadeiro efeito vinculante nos processos cíveis e frequentemente serviam de base para a decisão judicial. Contudo, com o aumento da produção literária jurídica começaram a surgir opiniões das mais diversas sobre o mesmo tema. Inicialmente, então, os tribunais civis tentaram lidar com o problema através do desenvolvimento da doutrina da 'opinião comum dos doutores'. Porém, como é natural, com o passar do tempo, a quantidade crescente de opiniões levou inevitavelmente a uma redução e, posteriormente, à perda de autoridade por parte dos doutrinadores. Isso considerando, ainda, que o entendimento doutrinário não estava mais relacionado com a alta qualidade dos seus escritos. (...) A proibição da citação doutrinária, assim, surgiu muito mais como uma reação dos juízes à grande quantidade de opiniões dos doutrinadores, nem sempre concordes entre si, bem como com a intenção de limitar o poder dos doutrinadores, enfatizando a soberania do Estado e, em especialmente, da função real. Além disso, essa regra foi resultado do mito do século XIX, que pregava que o texto da lei era exaustivo e única fonte na qual as soluções judiciais deveriam ser retiradas." (MEIRELLES, Edilton. A citação da doutrina nas decisões judiciais no direito comparado. Revista de Processo. v. 206, abr./2012. Acesso eletrônico.).
} 
Revista Eletrônica de Direito Processual - REDP.

Rio de Janeiro. Ano 12. Volume 19. Número 1. Janeiro a Abril de 2018

Periódico Quadrimestral da Pós-Graduação Stricto Sensu em Direito Processual da UERJ

Patrono: José Carlos Barbosa Moreira (in mem.). ISSN 1982-7636. pp. 193-213

www.redp.uerj.br

esteve associada a diversos fatores ${ }^{24}$, mas o enriquecimento da literatura também na

Inglaterra sepultou o entendimento.

Semelhantes barreiras inexistem em outros tantos países, sendo certo que o conhecimento e a referência doutrinária chegam a constituir fator de valorização da decisão nos Estados Unidos, em Portugal e na Alemanha, por exemplo.

Fechado o parêntesis, pode-se dizer que os fundamentos para o dever de motivação - ao qual se relaciona o direito de se obter uma resposta jurisdicional convincente - são variados. Barbosa Moreira elenca ao menos três.

A motivação tem um primeiro fundamento técnico, que presta auxílio às impugnações inerentes ao sistema jurisdicional. É a noção já mencionada nas Ordenações Filipinas: permitir avaliar a existência de interesse em recorrer e, se existente, a necessidade de reforma da decisão.

O mestre, porém, não restringe a importância técnica da fundamentação a esse aspecto endoprocessual: também a opinião pública merece conhecer o que foi decidido e por qual razão, não se tratando de privilégio dos interessados diretos ${ }^{25}$. Há ainda o interesse qualificado de alguns grupos, quando existir extensão subjetiva dos efeitos da sentença ou da coisa julgada, para além do sempre presente interesse doutrinário em conhecer como pensa o Judiciário.

Segundo fundamento é o persuasivo, ligado com a pacificação social, um dos escopos da jurisdição. Existindo decisões bem fundamentadas, imagina-se que as partes se convençam e se contentem mais facilmente com o resultado. Decorreria daí, pois, um desencorajamento aos recursos.

O terceiro fundamento decorre do direito de ser ouvido, atualmente considerado parte integrante do contraditório, condição sem a qual não há processo. $\mathrm{O}$ direito de ação pressupõe de per si a oportunidade de fazer valer suas razões em juízo, com ampla

\footnotetext{
24 “Alexandra Braun, no entanto, aponta que a resposta parece estar na combinação de vários fatores que surgiram entre final do século XVIII e início do século XIX. Assim ela explica que, por esta época, na Inglaterra, o valor do precedente era forte, mas ainda não vinculativo, e o Judiciário provavelmente sentiu a necessidade de afirmar sua própria autoridade e seu controle sobre o desenvolvimento do direito (common law). Necessidade essa causada pelo crescimento da literatura jurídica. 'A proliferação de livros de direito tornou-se objeto de crescente preocupação do Judiciário (the bar).' Sentiu-se, então, que era necessário manter certo controle sobre quais textos estariam autorizados ou não a serem invocados como de doutrina, de modo a servirem de base para a decisão judicial.” (MEIRELLES, Edilton. Op. cit.)

${ }^{25}$ BARBOSA MOREIRA, Op. cit., p. 90.
} 
Revista Eletrônica de Direito Processual - REDP.

Rio de Janeiro. Ano 12. Volume 19. Número 1. Janeiro a Abril de 2018

Periódico Quadrimestral da Pós-Graduação Stricto Sensu em Direito Processual da UERJ

Patrono: José Carlos Barbosa Moreira (in mem.). ISSN 1982-7636. pp. 193-213

www.redp.uerj.br

possibilidade de influir na decisão - o que só é verificável mediante a motivação da

resposta judicial.

A motivação ainda se reveste do caráter de garantia dos jurisdicionados ${ }^{26}$, apta a assegurar o controle da imparcialidade do magistrado e da legalidade da decisão, em especial nos casos em que o legislador tenha deixado certa margem de discricionariedade ao lançar mão de conceitos jurídicos indeterminados ou de cláusulas gerais ${ }^{27}$.

Observou com precisão Daniel Mitidiero ${ }^{28}$ que, com a adoção da teoria lógicoargumentativa da interpretação, o Judiciário passa a escolher entre vários significados possíveis, realizando autêntica interpretazione-attivitá. Caberá à argumentação do intérprete o controle racional dos limites dessa proativa interpretação, o que, concretamente, se dará por meio da detida análise dos fundamentos externados pelo órgão prolator da decisão.

\footnotetext{
26 "O exercício do poder só se considera legítimo quando observa o princípio da legalidade. No processo, o juiz deve observar as regras do procedimento, destacando-se o dever de fundamentar as suas decisões. Este dever é uma decorrência natural do acesso à justiça e do devido processo legal, garantias expressamente asseguradas pela Constituição (art. 5. ${ }^{\circ}$ XXXV e LIV e art. 93, IX). A motivação serve de garantia para as partes, como contraponto à liberdade que o magistrado tem para decidir de acordo com seu livre convencimento. Ela também permite um controle da adequada prestação jurisdicional pelas partes e terceiros (sociedade como um todo), pelos próprios órgãos jurisdicionais - caso dos Tribunais hierarquicamente superiores - e, ainda, por aqueles que exercem outra forma de controle, como o Conselho Nacional de Justiça - CNJ." (CARNEIRO, Paulo Cezar Pinheiro. Comentário ao art. 11. In: WAMBIER, Teresa Arruda Alvim et al [coords.]. Breves comentários ao novo Código de Processo Civil. São Paulo: Revista dos Tribunais, 2015. Versão eletrônica.).

27 "Em seguida, não menos relevante se revela a constatação de que frequentemente o tecido legislativo apresenta margens de abertura. Com a finalidade de tornar a disposição adaptável às situações concretas ou para mantê-la atual, nada obstante o passar do tempo e as mudanças sociais, o legislador é levado com maior frequência a adotar técnicas legislativas elásticas, flexíveis e matizadas. A cultura jurídica, por sua vez, está empenhada, pelo menos há um século, em analisar as diversas formas de abertura da lei e a prospectar sutis, mas nem sempre claras, distinções, como os conceitos-válvula (Ventillbegriffe), os legal standards, as cláusulas gerais (Generalklauseln), os conceitos discricionários (Ermessensbegriffe), os conceitos jurídicos indeterminados (unbestimmten Rechtsbegriffe). Recentemente, também se difundiu a expressão 'vagueza das normas'. Mais adiante se terá ocasião de retornar sobre tais perfis, de momento mostra-se suficiente ressaltar que se trata de um complexo de técnicas legislativas por meio das quais se acaba por delegar ao juiz escolhas que o legislador não pode ou não quer fazer." (PICARDI, Nicola. Jurisdição e Processo. Rio de Janeiro: Forense, 2008, p. 7).

28 "A atividade interpretativa não constitui uma operação puramente lógica. O campo da aplicação da lógica na interpretação está circunscrito ao terreno da aferição dos nexos entre proposições e enunciados. Nesse sentido, a lógica tem um papel certamente importante, mas relativamente pequeno no processo de interpretação. A lógica nada diz, contudo, a respeito da escolha das normas que devem fazer parte do silogismo judiciário e do significado que deve ser atribuído aos enunciados linguísticos e às proposições de fato que o compõem. Em todos esses casos o que é determinante é a argumentação que é formulada pelo intérprete a favor das suas individualizações, valorações e escolhas. Vale dizer: o que importa aí é a argumentação jurídica." (MITIDIERO, Daniel. Cortes superiores e cortes supremas: do controle à interpretação, da jurisprudência ao precedente. 2. ed. São Paulo: Revista dos Tribunais, 2015, pp. 61-62).
} 
Revista Eletrônica de Direito Processual - REDP.

Rio de Janeiro. Ano 12. Volume 19. Número 1. Janeiro a Abril de 2018

Periódico Quadrimestral da Pós-Graduação Stricto Sensu em Direito Processual da UERJ

Patrono: José Carlos Barbosa Moreira (in mem.). ISSN 1982-7636. pp. 193-213

www.redp.uerj.br

Enriquecendo essa visão, Rodolfo Mancuso, após verificar a dicotomia norma-

legislada $v s$. norma-judicada (esta última a definitiva), fala em uma perspectiva atualizada e contextualizada da livre convicção ${ }^{29}$. A norma extraída do enunciado, portanto, enriquece

o sistema jurídico, mas sua justificação judicial é pressuposto de existência do ato jurisdicional.

Também são relevantes as funções da motivação, como destacou e estruturou

Michele Taruffo: controle endoprocessual, controle exoprocessual e controle do sistema de precedentes.

As duas primeiras funções acabam por estar relacionadas/incluídas no fundamento técnico enunciado por Barbosa Moreira. $\mathrm{O}$ controle endoprocessual está voltado às partes (decidir se há interesse recursal) e aos julgadores do recurso, possuindo como objeto o controle de fato (valoração e seleção das provas) e o controle de direito (escolha e interpretação das normas aplicadas). Trata-se da função racionalizante da motivação ${ }^{30}$, inexistente nos sistemas onde vige a íntima convicção.

De outra parte, está o controle extraprocessual, relacionado à própria Administração da Justiça, para assegurar a todas as pessoas, em nome de quem a justiça é administrada e prestada, e não apenas às partes, a oportunidade de conhecer e comprovar o

\footnotetext{
29 "Sem embargo, a questão segue controvertida, podendo-se ponderar que, se é verdade que o primado das obrigações comissivas e omissivas no país é centrado na norma legal (CF, art. $5 .^{\circ}$, II) - dada sua eficácia geral, abstrata e impessoal - não é menos verdade que o precípuo e definitivo entendimento sobre o conteúdo (extensão/compreensão) da norma legal vem deferido ao Judiciário, mormente através de seus produtos finais otimizados: jurisprudência dominante ou sumulada; questões de ordem firmadas no Pleno ou no Órgão Especial dos tribunais; acórdão em incidente de assunção de competência, decisões-quadro em REs e RESps repetitivos; acórdãos no controle abstrato de constitucionalidade; acórdão que firma a tese jurídica no IRDR. De resto, é bem de ver que a igualdade de todos perante a lei (CF, art. 5. ${ }^{\circ}$, caput) pouco agregaria, efetivamente, à isonomia e à segurança jurídica, a se prosseguir num ambiente de dispersão jurisprudencial excessiva, no qual ninguém está seguro de seus direitos, nem consciente de suas obrigações, assim no setor público como no privado; antes, impende que a igualdade se preserve, assim perante a norma legislada aquela forjada no Legislativo - como em face da norma judicada, a saber, aquela que tem sua passagem judiciária, vindo interpretada para aplicação ao caso concreto." (MANCUSO, Rodolfo de Camargo. Incidente de Resolução de Demandas Repetitivas: a luta contra a dispersão jurisprudencial excessiva. São Paulo: Revista dos Tribunais, 2016, pp. 271-272)

30 "Si se tiene en cuenta el hecho de que -como ya hemos dicho varias veces- una 'buena' motivación debe consistir en un conjunto de argumentos justificativos lógicamente estructurados en grado de formar una justificación racional de la decisión, se puede entonces observar que la motivación también posee una función esencialmente 'racionalizante'. De hecho, esta lleva a que el Juez realice un ejercicio racional y no sólo se base en intuiciones subjetivas no justificables. Como se mencionó anteriormente, si el Juez 'inteligente' sabe que deberá justificar racionalmente su decisión, se puede intuir que para llegar a su fallo haga uso de criterios lógicos y racionales, que finalmente deberá plasmar en la motivación de la sentencia.

Todo ello supone, por supuesto, que se adopte una concepción racional de la decisión y de su justificación." (TARUFFO, Michele. Apuntes sobre las funciones de la motivación. Revista Iberoamericana de Derecho Procesal.v. 4, jul./dez. 2016. Acesso eletrônico.)
} 
Revista Eletrônica de Direito Processual - REDP.

Rio de Janeiro. Ano 12. Volume 19. Número 1. Janeiro a Abril de 2018

Periódico Quadrimestral da Pós-Graduação Stricto Sensu em Direito Processual da UERJ

Patrono: José Carlos Barbosa Moreira (in mem.). ISSN 1982-7636. pp. 193-213

www.redp.uerj.br

fundamento das decisões judiciais, de modo a evitar arbitrariedades no exercício do

$\operatorname{poder}^{31}$. Seu objeto, assim, é o controle fático e jurídico das decisões, em especial no que se refere ao respeito pelas garantias fundamentais.

A terceira função da motivação está relacionada ao sistema de precedentes, uma vez que é ínsito ao sistema do stare decisis o conhecimento da ratio decidendi dos casos preteritamente julgados e que, com o decorrer do tempo, passam a gozar do status de precedente. Para conhecer qual precedente se aplicará nos casos posteriores e o que efetivamente constitui precedente, dentro de cada decisão, é que não se negocia a importância da motivação das decisões.

Por isso, aliás, é que, na Inglaterra, mesmo inexistindo obrigação genérica de fundamentação, os magistrados, inclusive os de primeiro grau, expõem satisfatoriamente os seus argumentos nas decisões. Nos Estados Unidos, os julgadores de segundo e último grau igualmente o fazem. A criação da técnica das unpublished opinions, contudo, não deixa de ser interessante, revelando que também em sistemas jurídicos de outras matrizes a grande quantidade de processos tem levado à necessidade de mitigar o dever de motivação ao essencial ${ }^{32}$.

31 "Esto implica un cambio radical de perspectiva: mientras que el control endoprocesal se refiere principalmente a las partes, incluso desde el punto de vista del control por apelación, la posibilidad de control extraprocesal se refiere, principalmente, a una garantía democrática de la Administración de Justicia." (TARUFFO, Michele. Apuntes sobre las funciones de la motivación. Revista Iberoamericana de Derecho Procesal. v. 4, jul./dez. 2016. Acesso eletrônico.)

32 "Como forma de contornar os problemas advindos da proliferação de decisões judiciais e de sua invocação como precedente, no Congresso Judicial dos Estados Unidos, realizado em março de 1964, houve a recomendação para que os juízes das cortes de apelação e os juízes das cortes distritais - primeiro grau de jurisdição - autorizassem apenas a 'publicação' das decisões que tivessem valor como precedente. O tema evoluiu para a criação, pelas cortes federais norte-americanas, da técnica de limitação da 'publicação' das decisões judiciais, denominada de unpublished opinions. A tradução literal da expressão unpublished opinions ('decisões não publicadas') pode não apenas gerar confusão de conceitos, como também produzir aversão apriorística ao instituto. A expressão não significa que se trata de decisões que não sejam públicas ou, em outros termos, decisões sigilosas. Assim como no Brasil, a regra do direito norte-americano é a publicidade dos julgamentos e das decisões judiciais. As unpublished opinions são, na verdade, decisões proferidas pelos tribunais sem autoridade de precedente vinculante. Embora digam respeito a casos publicamente decididos e posteriormente divulgados, muitas vezes até mesmo em páginas eletrônicas dos tribunais, o termo unpublished refere-se ao fato de essas decisões não serem incluídas em base de dados impressa, para a consulta de precedentes. Constituem, assim, técnica a ser utilizada para evitar a excessiva profusão de precedentes, para casos que não justificariam o debate mais aprofundado sobre standards de conduta, o que onera a atividade de edição, armazenamento e consulta dos repositórios. Paralelamente, essa técnica visa a facilitar a atividade dos tribunais, que não estão obrigados a fundamentar de maneira exaustiva casos mais simples e não reconhecidos como relevantes para a formação de precedentes. Dados estatísticos revelam que as unpublished opinions são consideravelmente mais curtas do que as decisões enviadas aos repositórios de publicação. Estudos revelam que a maioria dos textos das unpublished opinions são inferiores a 300 palavras e, em vários casos, inferiores a 100 palavras. A título comparativo, as published opinions apresentam, em sua maioria, de 1.000 a 3.000 palavras. A menor exigência de fundamentação 
Revista Eletrônica de Direito Processual - REDP.

Rio de Janeiro. Ano 12. Volume 19. Número 1. Janeiro a Abril de 2018

Periódico Quadrimestral da Pós-Graduação Stricto Sensu em Direito Processual da UERJ

Patrono: José Carlos Barbosa Moreira (in mem.). ISSN 1982-7636. pp. 193-213

www.redp.uerj.br

Essa terceira função da motivação se aproxima a cada dia mais dos sistemas de tradição romano-germânica, devendo se acentuar no Brasil em razão da dinâmica de respeito às decisões judiciais e aos precedentes, preconizada no artigo 927 do CPC de 2015 33

\section{O dever de motivação no Código de Processo Civil de 2015: senso e contrassenso.}

No atual contexto pátrio, o CPC de 2015 trata a motivação das decisões judiciais em destaque em dois artigos, sem prejuízo da reafirmação da exigência ou da sua flexibilização ou quase eliminação em alguns outros.

O primeiro deles está entre as normas fundamentais do processo civil. O artigo 11 é, assim, a primeira morada dos princípios da publicidade processual e da motivação das decisões judiciais, que constitui objeto deste estudo, ao afirmar que todos os julgamentos dos órgãos do Poder Judiciário serão públicos e fundamentadas todas as decisões, sob pena de nulidade. Cuida-se de uma autêntica reprodução da garantia prevista no artigo 93, inciso IX, da Constituição.

O segundo está no artigo 489, inciso II, ao reconhecer como elemento essencial da sentença os seus fundamentos, devendo o juiz analisar as questões de fato e de direito. $\mathrm{O}$ parágrafo $1^{\circ}$ desse artigo estabelece, de modo claro, com ares de obviedade ${ }^{34}$, que não se considera fundamentada qualquer decisão judicial, seja ela interlocutória, sentença ou acórdão, que ${ }^{35}$ :

permite ganhos de aceleração do processo e de aumento da produtividade do tribunal." (BARIONI, Rodrigo. As unpublished opinions do direito norte-americano: contribuição para a assunção de competência. Revista de Processo. v. 261, nov. 2016, p. 403)

33 “A justificação da decisão judicial serve a uma dupla finalidade, que correspondem aos fins do processo civil no Estado Constitucional: se, de um lado, serve como processo discursivo e racional de determinação de sentido para aplicação ao caso, mostrando-se, nessa perspectiva, como um discurso endereçado a resolver o caso concreto com justiça, de outro, o seu resultado contribui para a conformação da ordem jurídica e para a determinação do direito, revelando-se um discurso endereçado à sociedade em geral" (MOTTA, Otávio. Aspectos da justificação das decisões judiciais em perspectiva comparada. Revista de Processo Comparado. v. 2, jul./dez. 2015. Acesso eletrônico.)

34 “Com efeito, não é admissível que o juiz transcreva o texto sem justificar o sentido normativo a ele outorgado, como se o enunciado transcrito não devesse ser interpretado ou como se contivesse em si mesmo um sentido único previamente determinado. O que o art. 489, § 1.o, I, do CPC/2015 pretende, em última análise, é impedir a falsa fundamentação que, ao transcrever o texto normativo, esconde as verdadeiras escolhas interpretativas." (MOTTA, Otávio. Aspectos da justificação das decisões judiciais em perspectiva comparada. Revista de Processo Comparado. v. 2, jul./dez. 2015. Acesso eletrônico.)

35 "A era alfaiataria de alta costura se avizinha. É decretada a morte da farra principiológica. Normas de caráter genérico, destinadas a iluminar o caminho do aplicador do direito e a indicar os rumos a serem seguidos foram confundidas com portais de abertura para a discricionariedade, como se toda a vontade do julgador pudesse caber em um princípio e este pudesse ser o escudo utilizado para a defesa de tudo o que 
Revista Eletrônica de Direito Processual - REDP.

Rio de Janeiro. Ano 12. Volume 19. Número 1. Janeiro a Abril de 2018

Periódico Quadrimestral da Pós-Graduação Stricto Sensu em Direito Processual da UERJ

Patrono: José Carlos Barbosa Moreira (in mem.). ISSN 1982-7636. pp. 193-213

www.redp.uerj.br

I - se limitar à indicação, à reprodução ou à paráfrase de ato normativo, sem explicar sua

relação com a causa ou a questão decidida;

II - empregar conceitos jurídicos indeterminados, sem explicar o motivo concreto de sua incidência no caso;

III - invocar motivos que se prestariam a justificar qualquer outra decisão;

IV - não enfrentar todos os argumentos deduzidos no processo capazes de, em tese, infirmar a conclusão adotada pelo julgador;

V - se limitar a invocar precedente ou enunciado de súmula, sem identificar seus fundamentos determinantes nem demonstrar que o caso sob julgamento se ajusta àqueles fundamentos;

VI - deixar de seguir enunciado de súmula, jurisprudência ou precedente invocado pela parte, sem demonstrar a existência de distinção no caso em julgamento ou a superação do entendimento.

Não obstante a amplitude do comando, existem ponderações de relevo sobre a extensão da inteireza da motivação. Cândido Dinamarco e Bruno Lopes, por exemplo, traçam distinção entre as omissões sobre pontos centrais e sobre pontos colaterais da decisão, elegendo apenas aquelas como aptas a nulificar o pronunciamento, pois capazes de mudar o rumo do julgamento, por si sós ${ }^{36}$.

Algumas vozes, por sua vez, não se animaram muito com a simples alteração legal. Erik Navarro Wolkart ponderou que o déficit qualitativo da prestação jurisdicional não se deveria exclusivamente por conta da atuação judicante, cabendo exigir que as partes melhorem seu poderio argumentativo - caso contrário, a nulidade decorrente da débil fundamentação seria produto de sua negligência, não cabendo ser suscitada por quem a deu causa $^{37}$.

frequentava a consciência daquele." (HELLMAN, Renê Francisco. Sobre como será difícil julgar com o Novo Código de Processo Civil: do prêt-à-porter à alta costura decisória. Revista de Processo. v. 239, jan. 2015. Acesso eletrônico.).

${ }^{36}$ DINAMARCO, Cândido Rangel; LOPES, Bruno Vasconselos Carrilho. Teoria geral do novo processo civil. 2. ed. São Paulo: Malheiros, 2017, p. 73.

37 "No entanto hoje, essa norma sozinha, a depender do modo de interpretação e de seu encarte no sistema de nulidades, é capaz de nulificar a quase totalidade das sentenças e acórdãos de mérito proferidos no Brasil. E temos disso a absoluta certeza, lastreada no notório costume do juiz brasileiro de abordar na sentença apenas aquilo que entende relevante, sustentado pela jurisprudência pacífica dos Tribunais Superiores. (...) Essa é, portanto, a única novidade do $\S 1.0$ do art. 489: impor, como reforço das formas do processo e sob pena de reconhecimento de nulidade caso haja prejuízo, que a petição inicial, a contestação e a sentença atenham-se 
Revista Eletrônica de Direito Processual - REDP.

Rio de Janeiro. Ano 12. Volume 19. Número 1. Janeiro a Abril de 2018

Periódico Quadrimestral da Pós-Graduação Stricto Sensu em Direito Processual da UERJ

Patrono: José Carlos Barbosa Moreira (in mem.). ISSN 1982-7636. pp. 193-213

www.redp.uerj.br

Francisco Glauber Pessoa Alves corroborou esse entendimento ${ }^{38}$ e, ao analisar

detidamente a nova legislação, verificou pontos de dúvida. A não repetição do artigo 459

da codificação anterior seria uma delas, gerando dúvida se, doravante, julgamentos que não

enfrentem o mérito não poderiam ser sucintamente fundamentados. $\mathrm{O}$ autor advoga que o

princípio da economia processual autoriza a manutenção da norma que desapareceu.

Outra dúvida se refere à necessidade de relatório nas decisões interlocutórias, negada pelo referido autor, que enxerga na topografia normativa uma justificativa para sua dispensa $^{39}$. A respeito da dispensabilidade do relatório, aliás, existe entendimento no sentido de que o princípio da celeridade a justificaria amplamente, devendo o juiz utilizar o tempo de sua elaboração com outros feitos, ante a ausência de prejuízo ${ }^{40}$.

Em outras passagens, o Código seguiu prestigiando a fundamentação das decisões, como é o caso do artigo 371, que impõe aos juízes, em todos os graus de jurisdição, a apreciação da prova e dos demais elementos existentes nos autos, independentemente da parte que os houver produzido, com a indicação na decisão das razões da formação de seu convencimento.

aos fatos subjacentes à causa, abstendo-se de argumentos ou fundamentos abstratos ou genéricos que com ela não tenham relação explícita e fundamentada.” (WOLKART, Erik Navarro. Novo Código de Processo Civil x sistema processual de nulidades. Xeque-mate?. Revista de Processo. v. 250, dez. 2015. Acesso eletrônico.).

38 "Terceiro contorno: é importante dizer que o dever de escorreita argumentação não se aplica somente ao magistrado. De fato, também a parte deve expor de forma clara, precisa, a ser entendida pelo julgador. Muitas vezes, mais do que seria razoável, isso não ocorre. Existem petições que pecam pelo generalismo. Tecnicamente falando, sequer mereceriam processamento sem devida correção." (ALVES, Francisco Glauber Pessoa. Fundamentação judicial no Novo Código de Processo Civil. Revista de Processo. v. 253, mar. 2016. Acesso eletrônico.).

39 “O silêncio eloquente afasta qualquer dúvida. E há uma razão evidente para isso: não se há de exigir relatório para decisões interlocutórias, porque a gênese dos problemas que o NCPC procura extirpar é a ausência de fundamentação e não a falta de relatório. Seria formalizar desnecessariamente o processo civil geral a demanda por relatórios em decisões interlocutórias, quando isso nunca existiu no CPC. Daí porque, mais uma vez, não há como concordar com considerações, calcadas, a nosso ver, em premissas de institutos próprios e inconfundíveis (decisões que resolvam o mérito e decisões interlocutórias), entendendo imperioso o relatório em todas as decisões interlocutórias." (Idem, p. 61-62).

40 "Em que pese a literalidade do referido artigo do CPC, acreditamos que o relatório, ontologicamente, e ao contrário da fundamentação e do dispositivo, não é mais parte essencial da sentença e pode ser dispensado, com base no direito conferido a todos, de acesso aos meios que garantam a célere tramitação processual, desde que isto não cause prejuízo às partes. Fundamentação e decisum, sem a menor sombra de dúvida, não podem faltar à sentença. A ausência de qualquer delas desfiguraria seu conteúdo. Além disso, a fundamentação garante a parte contra a parcialidade do juiz e possibilita-lhe, em face do conhecimento das razões de decidir, insurgir-se e manejar eventual recurso. Mas a falta de relatório não necessariamente nos causa esse tipo de problema, porque o conteúdo do que seria o relatório, tradicionalmente, deve conter os nomes das partes, a suma do pedido e da resposta do réu, bem como o registro das principais ocorrências havidas no andamento do processo." (CARTAXO, Azevedo Hamilton; CRUZ, Luana Pedrosa de Figueiredo. A efetividade da prestação da tutela jurisdicional e a possibilidade de dispensa o relatório da sentença, em face do inciso LXXVIII, da CF/88. Revista de Processo. v. 157, mar. 2008. Acesso eletrônico.). 
Revista Eletrônica de Direito Processual - REDP.

Rio de Janeiro. Ano 12. Volume 19. Número 1. Janeiro a Abril de 2018

Periódico Quadrimestral da Pós-Graduação Stricto Sensu em Direito Processual da UERJ

Patrono: José Carlos Barbosa Moreira (in mem.). ISSN 1982-7636. pp. 193-213

www.redp.uerj.br

Nessa linha, um especial ônus argumentativo é imposto pelo Código ao tribunal quando da revisão da tese fixada em julgamento de caso repetitivo (artigo 927, §4º). Diante da obrigação de manter a jurisprudência íntegra, estável e coerente (artigo 926), não bastará jamais o mero voluntarismo para modificar o entendimento assentado.

Outros incidentes que gozam de ampla participação e eficácia receberam do legislador contornos mais exigentes quanto à motivação das decisões. É o que ocorre no Incidente de Resolução de Demandas Repetitivas, dado o artigo 984, $\S 2^{\circ}$ ( $O$ conteúdo do acórdão abrangerá a análise de todos os fundamentos suscitados concernentes à tese jurídica discutida, sejam favoráveis ou contrários), exigindo apreciação exauriente dos argumentos ventilados.

Também assim estava previsto para o julgamento dos recursos repetitivos. Porém, a Lei 13.256/2016, que reformulou o $\$ 3^{\circ}$ do artigo 1.038 ainda no período de vacatio do novo Código, retirou o vocábulo "todos” de sua redação, criando uma incongruência.

Atento à amplitude esperada da motivação das decisões, Otávio Motta lamentou que o nível de exigência só tenha sido elevado para os motivos jurídicos, sem uma exata correspondência para as razões fáticas da decisão ${ }^{41}$.

Existem, como se percebe, pontuais contrassensos internos ao próprio Código no que tange à motivação das decisões. Por vezes, e provavelmente de maneira involuntária, o legislador deu com uma mão e retirou com a outra a proteção que havia garantido às partes. A esse conjunto, acrescentamos mais um.

Como se sabe, a decisão que desrespeitar o parâmetro do artigo 489, §1 ${ }^{\circ}$, estará eivada de vício (o qual, em que pese a divergência acerca de sua natureza jurídica, cominará, no mínimo, de nulidade o ato decisório). Acontece que, adiante, quando trata da

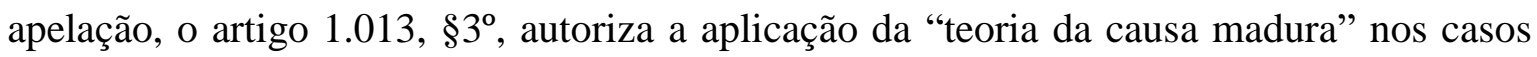
em que o tribunal decretar a nulidade de sentença justamente por falta de fundamentação. O tribunal estará, assim, autorizado a decidir desde logo o mérito, estando o processo em

\footnotetext{
41 "Se, de um lado, cuidou o Código de Processo Civil de 2015 de elevar o nível de motivação das decisões no âmbito normativo das escolhas interpretativas, de outro, deixou o legislador de 2015 de formular igual elevação no que concerne à justificação dos elementos fáticos da decisão. Vale insistir: a justificação do juízo de fato no processo é tão importante quanto a justificação do juízo de direito. O Código de Processo Civil de 2015 perdeu a oportunidade de deixar isso claro. Afora a necessidade de justificação quanto à qualificação jurídica do fato, não cuidou o Código de Processo Civil de 2015 da justificação a respeito da verificação das premissas de fato da decisão." (MOTTA, Otávio. Op. cit.).
} 
Revista Eletrônica de Direito Processual - REDP.

Rio de Janeiro. Ano 12. Volume 19. Número 1. Janeiro a Abril de 2018

Periódico Quadrimestral da Pós-Graduação Stricto Sensu em Direito Processual da UERJ

Patrono: José Carlos Barbosa Moreira (in mem.). ISSN 1982-7636. pp. 193-213

www.redp.uerj.br

condições de imediato julgamento, ainda que a fundamentação da sentença tenha sido imprestável.

Nesse contexto, se a matéria for apenas de direito, não havendo, portanto, controvérsia sobre os fatos e tampouco a necessidade de produção de outras provas, as linhas mestras dos princípios da economia processual e da celeridade até podem recomendar e justificar a dinamização do julgamento pela segunda instância, na medida em que ainda poderá haver oportunidade de impugnação da decisão junto aos tribunais superiores, observados os limites de cabimento dos respectivos recursos.

Quadro absolutamente diverso, porém, ocorrerá se a falta de fundamentação estiver relacionada à matéria de fato. Aqui, poderá a sentença ter declarado que o processo se encontrava em condições de julgamento, mascarando, com isso, pela linha de argumentação escolhida, a utilidade da prova eventualmente requerida pela parte. Se o tribunal tomar a afirmação da sentença, no que diz respeito à matéria de fato, como definitiva, e a partir dela aplicar a teoria da causa madura para suprir a falha de fundamentação, os prejuízos poderão ser irreversíveis, na medida em que, em linhas gerais, os tribunais superiores não voltarão a se debruçar sobre os contornos fáticos da controvérsia. $^{42}$

Também integra a lista de preocupação com o contrassenso legislativo, no que diz respeito à exigência de motivação, a restrição ao cabimento do agravo de instrumento contra decisões que, ao longo do procedimento comum, tiverem de alguma maneira limitado o acesso da parte aos meios de prova úteis e relevantes para a demonstração da sua tese ${ }^{43}$.

Isso porque, como observam Cândido Rangel Dinamarco e Bruno Vasconselos Carrilho Lopes, a decretação da nulidade, nesses casos, que acabará por ser inútil, vez que o tribunal avançará para o mérito, preenchendo a lacuna deixada pelo magistrado,

\footnotetext{
${ }^{42}$ Francesco Conte, em obra de fôlego sobre o assunto, chamou a atenção para um outro problema relacionado à técnica da motivação per relationem. Para o autor, é "imprestável que a motivação de uma decisão judiciária se limite a catapultar à outra motivação, de sorte que não seja possível individuar as razões que estão como fundamento de sua parte dispositiva. Cuida-se de verdadeiro câncer processual, pois o decisum padecerá, em regra, do vício de invalidade, com gravosas consequências impostas aos jurisdicionados, principalmente com o desperdício de tempo, de energia e, não menos importante, financeiro" (CONTE, Francesco. Sobre a motivação da sentença no processo civil: Estado constitucional democrático de direito, discurso justificativo e legitimação do exercício da jurisdição. Rio de Janeiro: Gramma, 2016, p. 772).

${ }^{43}$ DINAMARCO, Cândido Rangel; LOPES, Bruno Vasconselos Carrilho. Teoria geral do novo processo civil. 2. ed. São Paulo: Malheiros, 2017, p. 71-74.
} 
Revista Eletrônica de Direito Processual - REDP.

Rio de Janeiro. Ano 12. Volume 19. Número 1. Janeiro a Abril de 2018

Periódico Quadrimestral da Pós-Graduação Stricto Sensu em Direito Processual da UERJ

Patrono: José Carlos Barbosa Moreira (in mem.). ISSN 1982-7636. pp. 193-213

www.redp.uerj.br

reforçando as críticas direcionadas à teoria da causa madura na medida em que a sua aplicação, desmedida, poderá chegar ao ponto de se colocar em questionamento a real necessidade de motivação das decisões no primeiro grau.

Assim, com esse breve inventário, o que queremos demonstrar é que o conhecido anseio por eficiência ${ }^{44}$ pode produzir resultado contrário às promessas repetidas pelo legislador nas normas fundamentais do processo civil que abrem o novo Código ${ }^{45}$.

\section{Conclusão}

Explorou-se o dever de fundamentação das decisões judiciais. Primeiramente, viuse os momentos de positivação legal e, depois, de sua constitucionalização. Em seguida, traçou-se breve panorama mundial acerca dos níveis de proteção/exigência que o mesmo recebe.

Buscou-se dar conteúdo à referida garantia, nos moldes do que foi proposto por Barbosa Moreira, entre nós, e por Michele Taruffo, na doutrina estrangeira. Em seguida, foi proposta a definição dos fundamentos e das funções da motivação judicial.

Em um terceiro momento, apresentou-se o cenário brasileiro, especialmente após o advento do atual código de processo civil, o qual, sem sombra de dúvidas, fortaleceu o princípio e elevou o grau de exigência para o Poder Judiciário. De todo modo, encontramos situações em que a eficiência pode ser valor colidente com aqueles resultantes do dever de ampla e adequada fundamentação.

Fica a conclusão de que a exigência de motivação das decisões deve ser encarada de modo sério por todos aqueles que, de alguma forma, participam do processo judicial, devendo o tribunal evitar a aplicação da teoria da causa madura no julgamento das apelações sempre que a ausência de fundamentação da sentença puder prejudicar o direito

\footnotetext{
${ }^{44}$ A correta compreensão do princípio da eficiência passa pela produção do máximo de efeitos possíveis (produtividade), com o mínimo de esforço (economicidade), desde que não se viole a qualidade. Os vetores apontados se encontram em RODRIGUES, Eduardo Azeredo. O princípio da eficiência à luz da teoria dos princípios: aspectos dogmáticos de sua interpretação e aplicação. Rio de Janeiro: Lumen Juris, 2012, pp. 91-106. Por produtividade, tem-se o real aumento da produção; por economicidade, a redução dos custos dos meios; por qualidade, a noção de um serviço efetivamente bom, objetivamente. Menciona-se, ainda, a celeridade e presteza, que dizem respeito à otimização da relação tempo-custo-benefício, a desburocratização e a flexibilização, que envolvem o afastamento das estruturas-meios para o foco nos resultados.

${ }^{45}$ Atento à realidade prática do Judiciário, Lênio Streck e Ziel Lopes redigiram reflexão semelhante à ora externada em: E os doutores Chicó e João Grilo estão acabando com o artigo $489, \S 1^{\circ}$ do CPC. Consultor Jurídico. 3 ago. 2017. Disponível em: <http://www.conjur.com.br/2017-ago-03/senso-incomum-chico-joaogrilo-acabando-artigo-489-cpc>. Acesso em: 10 ago. 2017.
} 
Revista Eletrônica de Direito Processual - REDP.

Rio de Janeiro. Ano 12. Volume 19. Número 1. Janeiro a Abril de 2018

Periódico Quadrimestral da Pós-Graduação Stricto Sensu em Direito Processual da UERJ

Patrono: José Carlos Barbosa Moreira (in mem.). ISSN 1982-7636. pp. 193-213

www.redp.uerj.br

que as partes têm, fruto do amplo contraditório, de influir eficazmente na formação do convencimento do julgador para a obtenção, em tempo razoável, de uma decisão de mérito justa e efetiva (artigo $6^{\circ}$ ).

\section{REFERÊNCIAS BIBLIOGRÁFICAS:}

ALVES, Francisco Glauber Pessoa. Fundamentação judicial no Novo Código de Processo Civil. Revista de Processo. v. 253, mar. 2016.

ANDREWS, Neil. Decisões judiciais e o dever de fundamentar. Revista de Processo. v. 192, fev. 2011.

BARBOSA MOREIRA, José Carlos. A motivação das decisões judiciais como garantia inerente ao Estado Democrático de Direito. In: Temas de Direito Processual: segunda série. São Paulo: Saraiva, 1988. 2 ed.

BARIONI, Rodrigo. As unpublished opinions do direito norte-americano: contribuição para a assunção de competência. Revista de Processo. v. 261, nov. 2016.

CAPPELLETTI, Mauro; VIGORITTI, Vicenzo. Fundamental guarantees of the litigants in civil proceedings: Italy. In: Mauro Cappelletti; Denis Tallon (orgs.). Fundamental Guarantees of the Parties in Civil Litigation. Milano: Giuffrè, 1973.

CARNEIRO, Paulo Cezar Pinheiro. Comentário ao art. 11. In: WAMBIER, Teresa Arruda Alvim et al [coords.]. Breves comentários ao novo Código de Processo Civil. São Paulo: Revista dos Tribunais, 2015. Versão eletrônica.

CARTAXO, Azevedo Hamilton; CRUZ, Luana Pedrosa de Figueiredo. A efetividade da prestação da tutela jurisdicional e a possibilidade de dispensa o relatório da sentença, em face do inciso LXXVIII, da CF/88. Revista de Processo. v. 157, mar. 2008.

CONTE, Francesco. Sobre a motivação da sentença no processo civil: Estado constitucional democrático de direito, discurso justificativo e legitimação do exercício da jurisdição. Rio de Janeiro: Gramma, 2016.

DINAMARCO, Cândido Rangel; LOPES, Bruno Vasconselos Carrilho. Teoria geral do novo processo civil. 2. ed. São Paulo: Malheiros, 2017.

HELLMAN, Renê Francisco. Sobre como será difícil julgar com o Novo Código de Processo Civil: do prêt-à-porter à alta costura decisória. Revista de Processo. v. 239, jan. 2015. 
Revista Eletrônica de Direito Processual - REDP.

Rio de Janeiro. Ano 12. Volume 19. Número 1. Janeiro a Abril de 2018

Periódico Quadrimestral da Pós-Graduação Stricto Sensu em Direito Processual da UERJ

Patrono: José Carlos Barbosa Moreira (in mem.). ISSN 1982-7636. pp. 193-213

www.redp.uerj.br

LIEBMAN, Enrico Tulio. Do arbítrio à razão. Reflexões sobre a motivação das sentenças. Revista de Processo. v. 29.

MANCUSO, Rodolfo de Camargo. Incidente de Resolução de Demandas Repetitivas: a luta contra a dispersão jurisprudencial excessiva. São Paulo: Revista dos Tribunais, 2016.

MEIRELLES, Edilton. A citação da doutrina nas decisões judiciais no direito comparado. Revista de Processo. v. 206, abr./2012.

MELLO, Rogerio Licastro Torres de. Ponderações sobre a motivação das decisões judiciais. Revista de Processo. v. 111, jul./set. 2003.

MITIDIERO, Daniel. Cortes superiores e cortes supremas: do controle à interpretação, da jurisprudência ao precedente. 2. ed. São Paulo: Revista dos Tribunais, 2015.

MOTTA, Otávio. Aspectos da justificação das decisões judiciais em perspectiva comparada. Revista de Processo Comparado. v. 2, jul./dez. 2015.

PICARDI, Nicola. Jurisdição e Processo. Rio de Janeiro: Forense, 2008.

RODRIGUES, Eduardo Azeredo. O princípio da eficiência à luz da teoria dos princípios: aspectos dogmáticos de sua interpretação e aplicação. Rio de Janeiro: Lumen Juris, 2012.

TARUFFO, Michele. Apuntes sobre las funciones de la motivación. Revista Iberoamericana de Derecho Procesal. v. 4, jul./dez. 2016.

La motivazione della sentenza civile. Milano: CEDAM, 1975.

CARNEIRO, Athos Gusmão. Sentença mal fundamentada e sentença não fundamentada. Revista de Processo, v. 81, jan./mar. 1996.

WOLKART, Erik Navarro. Novo Código de Processo Civil x sistema processual de nulidades. Xeque-mate?. Revista de Processo. v. 250, dez. 2015. 